\title{
COMENTARIOS
}

\section{Beyond specimens: linking biological collections, functional ecology and biodiversity conservation}

\section{Más allá de los especímenes: uniendo colecciones biológicas, ecología funcional y conserva- ción de la biodiversidad}

\section{Dennis Castillo-Figueroa}

Pontificia Universidad Javeriana, Unidad de Ecología y Sistemática (UNESIS), Bogotá, Colombia. Código postal: 11001000.

Email Dennis Castillo-Figueroa: dennis.castillof@gmail.com

\begin{abstract}
Several anthropogenic pressures are threatening biodiversity and may increase in the next years, altering ecological processes and ecosystem services. Biological collections offer a rich source of information to develop studies of functional ecology and biodiversity conservation. Key information related to morphology, physiology and life history could be obtained through functional traits provided by specimens in biological collections. Additionally, museum collections present a great potential for document changes of habitat disturbance, using response/effect framework, functional diversity measures, and fluctuating asymmetry approaches. Despite limitations of specimens in data such as abundance, imprecisions in specimen's georeferencing, errors in taxonomic identification and the poor preservation state of some specimens, biological collections contain vast data banks, which could be useful in the contribution of key information for land use management and conservation planning.
\end{abstract}

Keywords: biodiversity; functional traits; ecological responses; ecosystem functioning; natural history museums.

\section{Resumen}

Varias presiones antropogénicas amenazan la biodiversidad y pueden aumentar en los próximos años, alterando procesos ecológicos y servicios ecosistémicos. Las colecciones biológicas ofrecen una abundante fuente de información para desarrollar estudios de ecología funcional y conservación de la biodiversidad. Información clave relacionada con morfología, fisiología e historia de vida puede ser obtenida a través de los rasgos funcionales proporcionados por los ejemplares de colecciones biológicas. Adicionalmente, las colecciones de los museos presentan un gran potencial para documentar cambios en la perturbación del hábitat usando el marco de efecto/respuesta, las medidas de diversidad funcional, y el enfoque de asimetría fluctuante. A pesar de las limitaciones de los especímenes en datos como la abundancia, imprecisiones en la georreferenciación de los especímenes, errores en la identificación taxonómica y el mal estado de conservación de algunos ejemplares, las colecciones biológicas contienen enormes bancos de datos que podrían ser útiles en el aporte de información clave para el manejo del uso del suelo y los planes de conservación.

Palabras clave: biodiversidad; rasgos funcionales; respuestas ecológicas; funcionamiento del ecosistema; museos de historia natural.

Citación:

Castillo-Figueroa D. 2018. Beyond specimens: linking biological collections, functional ecology and biodiversity conservation. Revista peruana de biología 25(3): 343 - 348 (Agosto 2018). doi: http://dx.doi. org/10.15381/rpb.v25i3.14246

Presentado: $\quad$ 29/01/2018

Información sobre los autores:

Publicado online: 25/09/2018

El autor declara no tener conflicto de intereses. 


\section{Introduction}

Biodiversity is essential for ecosystem functioning and its derived ecosystem services, which are critical for human welfare (Moreno \& Verdú 2007). Therefore, understanding ecological processes as well as factors that promotes functional responses in communities, has become a crucial issue for conservation planning (Chapin et al. 2000). Currently, the rising anthropogenic pressures are threatening biodiversity and may increase in the next years (Johnson et al. 2017), causing changes in properties of communities, ecological functions and ecosystem services. For instance, habitat loss, fragmentation, global climate change, and biological invasions are widely considered major threats to biodiversity (Bradshaw et al. 2009) and functional ecology studies provide key information, which may be cornerstone in biodiversity conservation efforts. In doing so, museum collections can be an invaluable tool that offers a rich source of material to develop studies of functional ecology.

Biological collections harbor the natural heritage of Earth's biodiversity (Fig. 1). Animal and herbarium collections, including tissues, eggs, gene samples, parasites associated with a specimen, audio and video recordings, field notes and environmental data, among other information (Fig. 2) (Gropp 2018), are indispensable resources to depict the biodiversity of the world (Suarez \& Tsutsui 2004). Hence, preservation of specimens is essential for saving biodiversity knowledge for the next generations (Segovia-Salcedo et al. 2015). More than 6500 museum collections and academic institutions have over 3 billion specimens preserving the natural history of the Earth (Ariño 2010, Simmons \& Muñoz-Saba 2005). Nevertheless, biological collections are not only a repository of voucher specimens; besides being fundamental as a vital resource for education and scientific formation of biologists (Cook et al. 2014), natural history museums have a key role in different research fields such as taxonomy, systematics, cladistics, physiology, morphology, evolution, biomedicine, biochemistry, bioprospection, molecular

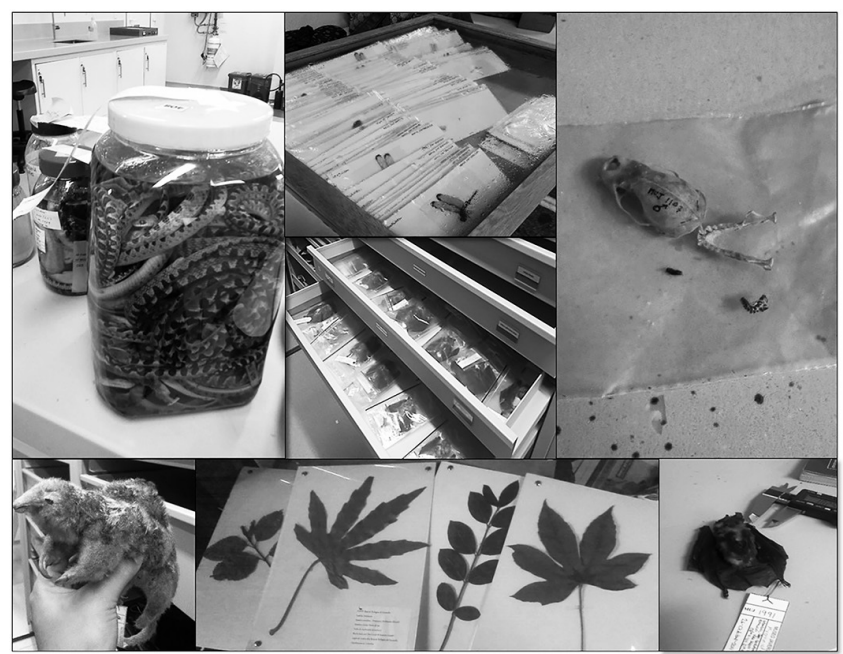

Figure 1. Diversity of specimens found in the natural history collections from Museo Javeriano de Historia Natural (Bogotá, Colombia).

studies, distribution of species, among others (Crisci \& Katinas 2017, Pyke \& Ehrlich 2010, Simmons \& Muñoz-Saba 2005).

Moreover, specimen collections are crucial to increase the knowledge of biological processes and document Earth's biodiversity (Rocha et al. 2014). Species descriptions (Kemp 2015, Rocha et al. 2014), studies on occurrence data (Nualart et al. 2017, Schatz 2002), identification of areas of endemism (Rocha et al. 2014, Davy 2005), estimation of species decline (Shaffer et al. 1998), studies of pathogens (Suarez \& Tsutsui 2004), description of morphological abnormalities (Castillo-Figueroa \& Pérez-Torres 2018), vectors of disease and ecotoxicology (Suarez \& Tsutsui 2004, Pyke \& Ehrlich 2010), to name only a few, are possible because of the biological collections and their associated

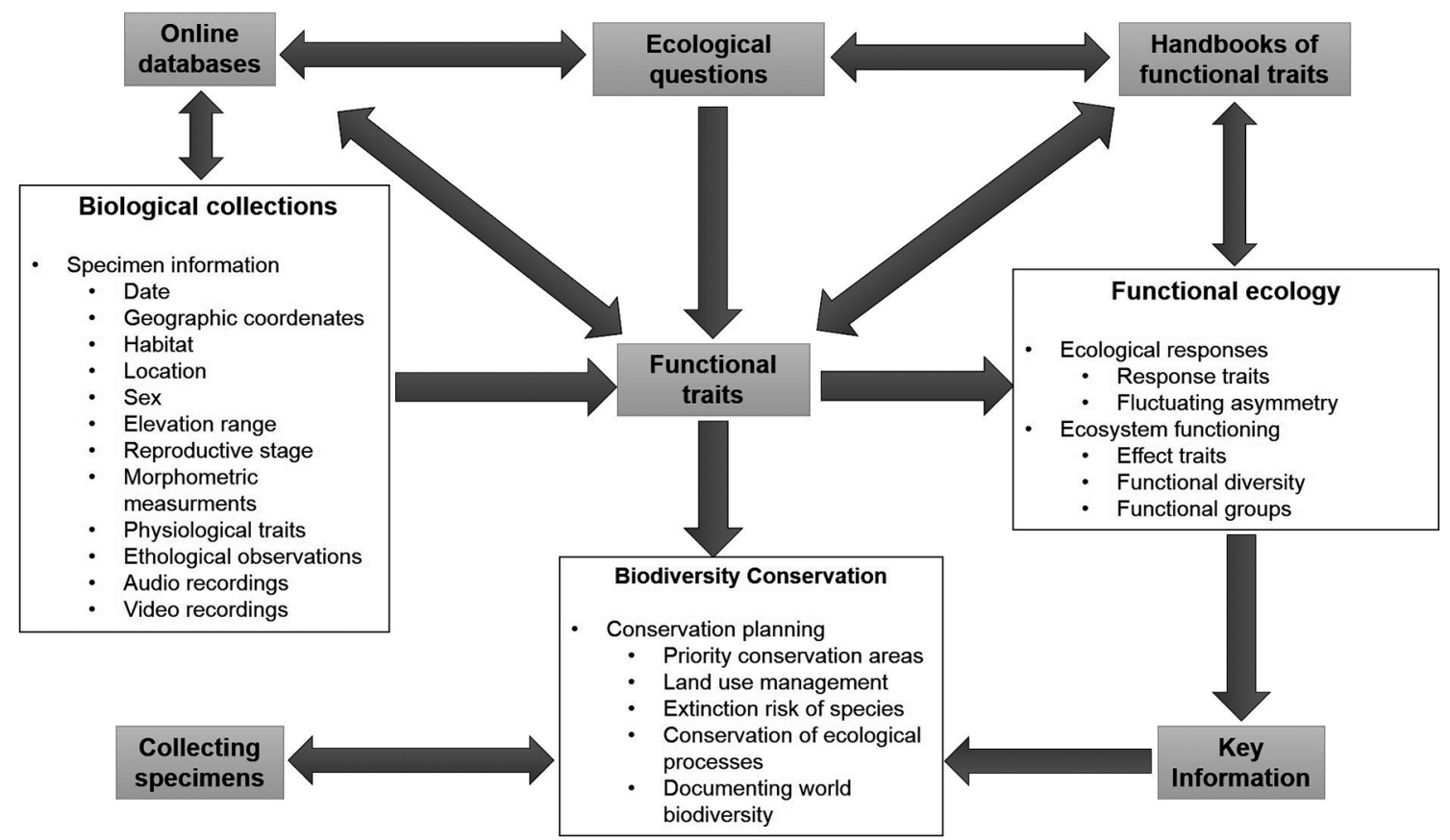

Figure 2. Linkages between biological collections, functional ecology and biodiversity conservation. 
data. Nonetheless, the museums of natural history have also a considerable potential to contribute to functional ecology and biodiversity conservation (Fig. 2), but thus far, these linkages have not been well established.

\section{The trait-based approach in functional ecology}

Functional ecology is a scientific discipline, which focus on understanding the ecological responses of species to environmental changes and its possible impact on community structure, likewise parse out the roles of species in ecosystem functioning (Salgado-Negret 2015). Questions such as, how do species influence ecosystem properties? How do species interact within a community? How do environmental gradients affect community structuring?, and what are the mechanisms that determinates community assembling? Are just few of the main questions which functional ecology pursuit (Salgado-Negret 2015, Garnier \& Navas 2012, McGill et al. 2006). In this sense, trait-based approach is an essential tool for functional ecology, being appropriate not only for capturing the interaction between species and their environments, but also for furnishing a functional perspective to the mechanisms of control on biodiversity and how it affects ecological processes at different levels of ecosystem organization (Garnier \& Navas 2012).

Particularly, functional traits are characters that beyond influencing the fitness of the organism (Violle et al. 2007), exhibit interactions with the environment, either reflecting the effect on the ecosystem process, or making evident the functional responses of species to environmental changes (Luck et al. 2012). Several examples have been displayed in plants and animals. In plants, functional traits such as life form, leaf lifespan, plant height and distribution of rooting depth are linked to climate and $\mathrm{CO}_{2}$ responses as well as soil resources responses and disturbance responses (Cornelissen et al. 2003). Additionally, leaf $\mathrm{N}$ and $\mathrm{P}$ concentration and twig dry matter content are related to effects on biogeochemical cycles (Cornelissen et al. 2003). In the case of animals, for mammals and reptiles, biomass and total length establishes a relationship with resource use in terms of quantity, energy expenditure and fluxes among trophic levels
(Gómez-Ortiz \& Moreno 2017). Likewise, in fishes, body depth and width, distance between the insertion of the pectoral fin to the bottom of the body, caudal fin depth and surface, and pectoral fin depth and surface are functional traits associated to locomotion, which is a measure related to habitat use, vertical position in the water column and hydrodynamism (CordovaTapia \& Zambrano 2016). These traits can be taken directly from individuals in the field, also from literature (especially if are life history traits), and many others can be obtained from museum specimens.

\section{Specimens, traits and conservation}

One of the advantages of biological collections is the use of their specimens to solve questions that original collectors never considered (Rocha et al. 2014, Pyke \& Ehrlich 2010). For instance, functional ecology may address key questions for biodiversity conservation using the material of scientific collections (Table 1). Through functional traits provided by specimens in biological collections, important data related to morphology, physiology and life history might be obtained. This information has a remarkable scope. On one hand, greater quantities of specimens that belong to different geographical localities, allows to know the distribution of functional traits and their correlations to environmental variables (Table 1) (Cortes-Gómez et al. 2015). On the other hand, many specimens collected on different dates or seasons enable to explore the functional changes over time, being useful for predictions in environmental changes (Table 1) (Cortes-Gómez et al. 2015). Using the response/effect framework (Lavorel \& Garnier 2002), functional traits can simultaneously predict the response of communities to environmental changes caused by anthropogenic pressures and their impact on ecosystem processes. Thus, two main components integrate this theoretical framework: (1) the response of communities to environmental changes (response traits) and (2) the effect on ecological processes of the ecosystems (effect traits) (Fig. 2).

Since habitat loss is one of the most important threats for biodiversity, the increase of anthropogenic pressures in natural habitats will have profound impacts on ecosystem functioning

Table 1. Questions in functional ecology that contribute to biodiversity conservation.

Questions

How does landscape management affect species fitness?

How can climate change can affect species?

What are the functional patterns of traits and its correlations with environmental variables?

How have the functional patterns of the species changed historically?

What are the differences between common and rare species in terms of their traits?

Which traits are related to threatened and no threatened species?

What are the critical regions for conservation based on functional diversity?
Contribution to biodiversity conservation

Identify sustainable productive systems for biodiversity conservation and ecosystem functioning

Prediction of future environmental changes provides integral management of biodiversity to prevent its effects on species survival.

Prediction of environmental changes in functionality of communities

Documenting the changes of habitat disturbance over the time for better land use management

Understand the functional contribution of both, rare and common species to the ecosystem functioning

The traits related to extinction risk are key to knowing how this risk can be avoided

Identify areas that harbor a great diversity of ecological processes provides useful criteria for selection of priority conservation areas 
(Bradshaw et al. 2009). Biological collections offer an enormous material to document the changes of habitat fragmentation and degradation (Crisci \& Katinas 2017), providing data over a vast time span which in many cases ranging from decades, centuries, or even millions of years ago to the present (Table 1 , Suarez $\&$ Tsutusui 2004). In this respect, approaches like fluctuating asymmetry, which is the random deviations from perfect symmetry in populations of organisms (Graham et al. 2010), can serve as a useful indicator of developmental instability in bilateral species, reflecting environmental and genetic stress in a particular spatial or temporal dimension (Pyke \& Ehrlich 2010, Leary \& Allendorf 1989). For example, fluctuating asymmetry in tarsus length of eight bird species from rainforest remnants in Kenya showed that this approach can be important as a cost-effective biomarker of environmental stress, allowing to take appropriate conservation action before birds become irreversibly affected by habitat fragmentation (Lens et al. 2002). To reach this conclusion, it was necessary to measure tarsus length of 133 specimens of six study species from natural history museums collected before the rainforest patches became severely deteriorated many decades ago (Lens et al. 2002). Other studies confirm the increase of fluctuating asymmetry with habitat disturbance when comparing contemporary bird species with the measurements of museum specimens collected 50 years ago in fragmented afrotropical forest (Lens et al. 1999). Therefore, museum collections are a source of baseline data to test the effect of spatial and temporal changes across species.

Even though museum collections may not provide abundances of specimens in particular locations, many functional traits taken from specimens can be used for functional diversity measures (i.e. functional groups, functional diversity indices) (Pla et al. 2012). In doing so, functional differences that species perform in ecosystems can be accounted (Petchey \& Gaston 2002). Functional diversity offers a basis to compare different land use scenarios, being idoneous to obtain information in order to achieve a comprehensive conservation planning (GonzálezMaya et al. 2017). Previously, museum specimens contributed to the delimitation of hotspots and ecoregions as well as the identification of priority conservation areas (Davy 2005), mainly estimating species richness despite of the natural sampling biases associated to the biological collections (Engemann et al. 2015). Implementing the functional diversity approach can complement the establishment of priority areas, because only taxonomical diversity approach assumes that all species contribute equally to ecosystem functioning (Berriozabal-Islas et al. 2017, García-Morales et al. 2016). By contrast, functional diversity represents the degree of functional differences among species, giving a better understanding on ecosystem functions, resilience and resistance (García-Morales et al. 2016). Thus far, besides the occurrence data provided by museums (Nualart et al. 2017), little use of functional traits, functional groups and functional diversity based on specimen collections have been applied in the establishment of priority areas (Table 1).

Finally, one of the global concerns is the effect of climate change on biodiversity. Particularly, herbaria collections contain potential sources of long-term data for the study of the influence of climate change in plant phenology. For instance, using herbarium specimens at Natural History Museum in London, changes in phenology were detected as a response of climate change in the orchid Ophrys sphaegodes (Robbirt et al. 2011).
Specifically, the increase in temperature was inversely proportional to the flowering time (Robbirt et al. 2011). Such kind of knowledge is important in order to identify the most vulnerable species to the climate change, which is useful in conservation planning for preventing ecological consequences on biodiversity (Table 1) (Nualart et al. 2017).

\section{New opportunities, bias and recommendations}

The Remarkable advances in natural history collections include their digitalization and the creation of associated online databases, such as the Global Biodiversity Information Facility (GBIF, http://www.gbif.org/), allowing the access to partial or even full collections in a pragmatically and easy way (Nualart et al. 2017, Cook et al. 2014, Smith \& Blagoderov 2012). This challenge demand collaborative endeavors between big data science, bioinformatics, and museum specimens (Cook et al. 2014). Moreover, online trait databases in plants (TRY, https://www.try db.org), corals (Coral Trait Database, https:// coraltraits.org), ants (GlobalAnts, http://globalants.org/), reptiles (Reptile Trait Database, http://scales.ckff.si/scaletool/ index.php?menu=6\&submenu=0), wasp and bees (Wasp \& Bees Database, http://scales.ckff.si/scaletool/?menu=6\&submenu=3) among other groups, provide a species-level data set compiled for analysis of life history and ecological characteristics, complementing the traits measured directly from the museum specimens (Fig. 2). On the other hand, the different handbooks and protocols of functional traits in different groups such as plants (Cornelissen et al. 2003), terrestrial invertebrates (Moretti et al. 2016), freshwater fishes (Zamudio et al. 2015), amphibians (Cortes-Gómez et al. 2015), birds (López-Ordońez et al. 2015) among others that are emerging, are helpful in the selection of functional traits according to the research aims, the standardized measuring of those traits, and their ecological interpretation (Fig. 2).

It is important to highlight that biological collections can include imprecisions and biases associated to specimens, which can create false patterns, so collection data should not be used indiscriminately (Nualart et al. 2017), without a rigorous method of inclusion-exclusion criteria. Accordingly, abnormal specimens with mutilations, deformations, and defects caused by bad preservation must be avoided, as well as functional traits modified by preparation process (Salgado-Negret 2015). In addition, collections might contain errors in the taxonomic identification of samples (Schatz 2002); hence, it is important to confirm species identity using taxonomic keys. Gaps in spatial and temporal data or imprecisions in specimen's georeferencing might be occur, especially in ancient data collected many decades ago (Stropp et al. 2016). In these cases, it is better to exclude dubious data to avoid spurious inferences. The expertise of researchers and curators in processing the specimens can reduce the imprecisions and mistakes in the data associated with a specimen (Nualart et al. 2017).

To take the functional traits, adult individuals are preferred, unless the research question incorporates other developmental stages. For studies of functional ecology, specimens should contain the largest amount of associated data, such as geographic location, date, habitat, sex, and elevation range, among others (Figure 2); however, the necessary data depends on the ecological questions and the objectives of the research of the study (SalgadoNegret 2015). In specimen-based research, it is recommendable 
to list the code of the specimens used during the study because this is the basis of reproducibility, which is a cornerstone of the scientific method (Funk et al. 2005).

As noted above, the limited sampling and the sparseness of specimens may obscure ecological patterns that are important in conservation efforts (Engemann et al. 2015). It is quite common, for example, that most specimens are collected close to the major cities, rivers, and roads, showing a clear effect of accessibility on sampling bias (Engemann et al. 2015). Hence, the manner in which natural history museums can be used to answer ecological questions depends on the nature of information associated with the specimens (Pyke \& Ehrlich 2010). In this sense, the absence of information associated with each specimen restrict the use of biological collections (Pyke \& Ehrlich 2010), so researchers have to formulate adequate questions according to the source of material available in collections.

\section{Final considerations}

In sum, although biological collections are certainly not perfect, they can provide an important source of information that forge links between functional ecology and biodiversity conservation through functional traits. Applied fields like Agroecology (Martin \& Isaac 2018), Urban ecology (Duncan et al. 2011), and Restoration ecology (Laughlin 2014), includes functional traits for a better description and prediction of environmental changes, which is becoming more important in the time of the Anthropocene. Biological collections harbors huge data banks, which can be useful in the advance of functional ecology; ecologists need to formulate questions that can be addressed according to the material available in the natural history museums. Getting back to the museums is critical for analyzing functional issues that provide critical information for biodiversity conservation.

Unfortunately, the grave threats that natural history collections are facing such as loss of curatorial expertise, budgets cuts, elimination of museum staffs, and the decline of collecting biological specimens (Kemp 2015, Bradley et al. 2014, Suarez \& Tsutusui 2004), are creating an impediment at a time when specimen-based research is being more important across several scientific disciplines (Bradley et al. 2014), within which functional ecology demonstrates a noteworthy growth in the last few decades. Therefore, it is quite important to keep collecting, curating, and maintaining the specimens in order to recognize their vital contribution to science and society (Cook et al. 2014). Consequently, financial support for biological collections is imperative as well as their use not just in research, but also in education to raise awareness about the irreplaceable repositories of information regarding all life on Earth that the human has recorded.

\section{Acknowledgements}

I am very grateful to Laura L. Garzón-Salamanca for the revision of the early version of the manuscript and Mariana Florian for important discussions about the role of biological collections in ecology. I also thank to María Alejandra Cely-Gómez for the revision of the English text and the two reviewers for insightful comments that substantially improved the manuscript.

\section{Literature cited}

Ariño A.H. 2010. Approaches to estimating the universe of natural history collections data. Biodiversity Informatics 7:81-92. https://doi.org/10.17161/bi.v7i2.3991.
Berriozabal-Islas C., L.M. Badillo-Saldaña, A. Ramírez-Bautista, et al. 2017. Effects of habitat disturbance on lizard functional diversity in a tropical dry forest of the pacific coast of Mexico Tropical Conservation Science (10):1-11. https:// doi.org/10.1177/1940082917704972.

Bradley R.D., L.C. Bradley, H.J. Garner, et al. 2014. Assessing the value of natural history collections and addressing issues regarding long-term growth and care. BioScience 64:1150-1158. https://doi.org/10.1093/biosci/biu166.

Bradshaw C.J.A, N.S. Sodhi \& B.W. Brook. 2009. Tropical turmoil: a biodiversity tragedy. Frontiers in Ecology and the Environment 7(2):79-87. https://doi.org/10.1890/070193.

Chapin S.F, E.S. Zavaleta, V.T Eviner, et al. 2000. Consequences of changing biodiversity. Nature 405:234-242. https://doi. org/10.1038/35012241.

Castillo-Figueroa D. \& J. Pérez-Torres. 2018. First records of wing defects in phyllostomid bats from Colombia. Journal of Bat Research \& Conservation 11(1). https://doi.org/10.14709/ BarbJ.11.1.2018.01.

Cook J., S.V. Edwards, E.A. Lacey, et al. 2014. Natural history collections as emerging resources for innovative education. BioScience 64: 725-734. https://doi.org/10.1093/biosci/biu096.

Cordova-Tapia F. \& L. Zambrano. 2016. Fish functional groups in a tropical wetland of the Yucatan Peninsula, Mexico. Neotropical Ichthyology 14(2):e150162. https://doi. org/10.1590/1982-0224-20150162.

Cornelissen J.H.C, S. Lavorel, E. Garnier, et al. 2003. A handbook of protocols for standardized and easy measurement of plant functional traits worldwide. Australian Journal of Botany 51:335-380. https://doi.org/10.1071/BT02124.

Cortes-Gómez A.M., M.P. Ramírez-Pinilla \& N. Urbina-Cardona. 2015. Protocolo para la medición de rasgos funcionales en anfibios, in: B. Salgado-Negret (Ed.), La Ecología funcional como aproximación al estudio, manejo y conservación de la biodiversidad: protocolos y aplicaciones. Instituto de Investigación de Recursos Biológicos Alexander von Humboldt $(\mathrm{IAvH})$, pp. 126-180.

Crisci J.V. \& L. Katinas. 2017. Las colecciones de historia natural: memoria colectiva de la humanidad. Museo 29:23-30.

Davy A.J. 2005. Museum specimens breathe life into plant conservation? Trends in Ecology and Evolution 20:285-286. https:// doi.org/10.1016/j.tree.2005.04.015.

Duncan R.P., S.E. Clemants, R.T. Corlett, et al. 2011. Plant traits and extinction in urban areas: a meta-analysis of 11 cities. Global Ecology and Biogeography 20(4):509-519. https:// doi.org/10.2307/41239338.

Engemann K., B.J. Enquist, B. Sandel, et al. 2015. Limited sampling hampers "big data" estimation of species richness in a tropical biodiversity hotspot. Ecology and Evolution 5(3):807-820. https://doi.org/10.1002/ece3.1405.

Funk V.A., P.C. Hoch, A.L. Prather, et al. 2005. The importance of vouchers. Taxon 54(1):127-129. https://doi. org/10.2307/25065309.

García-Morales R., C.E. Moreno, E.I. Baldano, et al. 2016. Deforestation impacts on bat functional diversity in tropical landscapes. PLoS ONE 11(12) e0166765. https://doi. org/10.1371/journal. pone.0166765.

Garnier E. \& M.L. Navas. 2012. A trait-based approach to comparative functional plant ecology: concepts, methods and applications for agroecology. A review. Agronomy for Sustainable Development 32:365-399. https://doi.org/10.1007/ s13593-011-0036-y.

Gómez-Ortiz Y. \& Moreno C. 2017. La diversidad funcional en comunidades animales: una revisión que hace énfasis en los vertebrados. Animal Biodiversity and Conservation 40(2):165-174.

González-Maya J.F., E. Martínez-Meyer, R. Medellin, et al. 2017. Distribution of mammal functional diversity in the Neotropical realm: Influence of land-use and extinction risk. PLoS ONE 12(4):e0175931. https://doi.org/ 10.1371/ journal.pone.0175931.

Graham J.H., S. Raz, H. Hel-or, et al. 2010. Fluctuating asymmetry: methods, theory, and applications. Symmetry 2(2):466-540. https://doi.org/10.3390/sym2020466. 
Gropp R. 2018. Specimens, Collections, and Tools for Future Biodiversity-Related Research. BioScience 68(1):3. https://doi. org/10.1093/biosci/bix155.

Johnson C.N., A. Balmford, B.W. Brook, et al. 2017. Biodiversity losses and conservation responses in the Anthropocene. Science 356(6335):270-275. https://doi.org/10.1126/ science.aam 9317.

Kemp C. 2015. The endangered dead. Nature 518:293. https://doi. org/10.1038/518292a

Laughlin D. C. 2014. Applying trait-based models to achieve functional targets for theory-driven ecological restoration. Ecology Letters 17(7):771-784. https://doi.org/10.1111/ele.12288.

Lavorel S. \& E. Garnier. 2002. Predicting changes in community composition and ecosystem functioning from plant traits: revisiting the Holy Grail. Functional Ecology 16(5):545-556. https://doi.org/10.1046/j.1365-2435.2002.00664.x

Leary R.F. \& F.W. Allendorf. 1989. Fluctuating asymmetry as an indicator of stress: implications for conservation biology. Trends in Ecology and Evolution 4(7):214-217. https:// doi.org/10.1016/0169-5347(89)90077-3.

Lens L., S. Van Dongen, K. Norris, et al. 2002. Avian persistence in fragmented rainforest. Science 298:1236-1238. https://doi. org/10.1126/science. 1075664

Lens L., S. Van Dongen, C.M. Wilder, et al. 1999. Fluctuating asymmetry increases with hábitat disturbance in seven bird species of a fragmented afrotropical forest. Proceedings of the Royal Society of London Series B 266(1425):1241.1246. https:// doi.org/10.1098/rspb.1999.0769.

López-Ordoñez J.P., G. Stiles \& J.L. Parra-Vergara. 2015. Protocolo para la medición de rasgos funcionales en aves, in: B. Salgado-Negret (Ed.), La Ecología funcional como aproximación al estudio, manejo y conservación de la biodiversidad: protocolos y aplicaciones. Instituto de Investigación de Recursos Biológicos Alexander von Humboldt (IAvH), pp. 80-126.

Luck G., S. Lavorel, S. McIntyre, et al. 2012. Improving the application of vertebrate trait-based frameworks to the study of ecosystem services. Journal of Animal Ecology 81(5):1065-1076. https://doi.org/10.1111/j.1365-2656.2012.01974.x

McGill B.J., B.J. Enquist, E. Weiher, et al. 2006. Rebuilding community ecology from functional traits. Trends in Ecology and Evolution 21:178-185. https://doi.org/10.1016/j. tree.2006.02.002.

Martin A.R. \& M.E. Isaac. 2018. Functional traits in agroecology: Advancing description and prediction in agroecosystems. Journal of Applied Ecology 55(1):5-11. https://doi. org/10.1111/1365-2664.13039.

Moreno C.E. \& J.M. Verdú. 2007. ¿Por qué preocuparnos por la pérdida de la biodiversidad? : relaciones entre biodiversidad, servicios de los ecosistemas y bienestar humano. Cuadernos de Biodiversidad 23: 11-17. https://doi.org/10.14198/ cdbio.2007.23.02.

Moretti, M., A.T.C. Dias, F. De Bello. 2017. Handbook of protocols for standardized measurement of terrestrial invertebrate functional traits. Functional Ecology, 31(3): 558-567. https://doi.org/10.1111/1365-2435.12776.

Nualart N., N. Ibañez., I. Soriano \& J. López-Pujol. 2017. Assessing the Relevance of Herbarium Collections as Tools for Conservation Biology. Botanical Review 83(3):303-325. https:// doi.org/10.1007/s12229-017-9188-z.
Petchey O.L \& K.J. Gaston. 2002. Extinction and the loss of functional diversity. Proceedings of the royal society B 269(1501):17211727. https://doi.org/10.1098/rspb.2002.2073.

Pla L., F. Casanoves \& J. Di Rienzo. 2012. Quantifiying functional diversity. Springer. 98pp.

Pyke G.H. \& P.R. Ehrlich. 2010. Biological collections and ecological/ environmental research: a review, some observations and a look to the future. Biological Reviews 85:247-266. https:// doi.org/10.1111/j.1469-185X.2009.00098.x.

Robbirt K.M., A.J. Davy, M.J. Hutchings, et al. 2011. Validation of biological collections as a source of phenological data for use in climate change studies: A case study with the orchid Ophrys sphegodes. Journal of Ecology 99:235-241. https:// doi.org/10.1111/j.1365-2745.2010.01727.x.

Rocha L.A., A. Aleixo, G. Allen, et al. 2014. Specimen collection: An essential tool. Science 344(6186):814-815. https://doi. org/10.1126/science.344.6186.814.

Salgado-Negret B. 2015. La ecología funcional como aproximación al estudio, manejo y conservación de la biodiversidad: protocolos y aplicaciones. Instituto de Investigación de Recursos Biológicos Alexander von Humboldt (IAvH). 234pp.

Schatz G.E. 2002. Taxonomy and herbaria in service of plant conservation: Lessons from Madagascar's endemic families. Annals of the Missouri Botanical Garden 89: 145-152. https://doi. org/10.2307/3298559.

Segovia-Salcedo C., L. Carrasco \& N. Acosta-Buenaño. 2015. Las colecciones biológicas: Los tesoros escondidos de un país mega-diverso. Revista ecuatoriana de medicina y ciencias biológicas 36: 83-88. doi: https://doi.org/10.26807/remcb. v36i1-2.278.

Shaffer H.B., R.N. Fisher \& C. Davidson. 1998. The role of natural history collections in documenting species declines. Trends in Ecology and Evolution 13(1):27-30. https://doi. org/10.1016/S0169-5347(97)01177-4.

Simmons J.E. \& Y. Muñoz. 2005. Cuidado, Manejo y Conservación de las Colecciones biológicas. Universidad Nacional de Colombia. 288pp.

Smith V.S. \& V. Blagoderov. 2012. Bringing collections out of the dark. ZooKeys 209:1-6. https://doi.org/10.3897/zookeys.209.3699.

Stropp J., R.J. Ladle, A.C.M. Malhado, et al. 2016. Mapping ignorance: 300 years of knowledge of flowering plants in Africa. Global Ecology and Biogeography 25:1085-1096. https:// doi.org/10.1111/geb.12468

Suarez A.V. \& N.D. Tsutsui. 2004. The value of museum collections for research and society. BioScience 54(1):66-74. https:// doi.org/10.1641/0006-3568(2004)054[0066:TVOMCF ]2.0.CO;2

Violle C., M.L. Navas., D. Vile, et al. 2007. Let the concept of trait be functional. Oikos 116(5):882-892. https://doi. org/10.1111/j.2007.0030-1299.15559.x.

Zamudio J.E., E.E.Herrera-Collazos, J.A. Maldonado-Ocampo, et al. 2015. Protocolo para la medición de rasgos funcionales en peces dulceacuícolas, in: B. Salgado-Negret (Ed.), La Ecología funcional como aproximación al estudio, manejo y conservación de la biodiversidad: protocolos y aplicaciones. Instituto de Investigación de Recursos Biológicos Alexander von Humboldt (IAvH), pp. 180-212. 